OPEN ACCESS

Edited by:

Romuald Lipcius,

College of William \& Mary,

United States

Reviewed by:

Andrew M. Fischer,

University of Tasmania, Australia

Jose M. Fariñas-Franco,

National University of Ireland Galway,

Ireland

*Correspondence:

Mark D. Bertness

Mark_Bertness@brown.edu

Specialty section:

This article was submitted to

Marine Conservation

and Sustainability,

a section of the journal

Frontiers in Marine Science

Received: 11 December 2018

Accepted: 17 April 2019

Published: 31 May 2019

Citation:

Crotty SM, Altieri AH, Bruno JF, Fischman H and Bertness MD (2019)

The Foundation for Building

the Conservation Capacity

of Community Ecology.

Front. Mar. Sci. 6:238.

doi: 10.3389/fmars.2019.00238

\section{The Foundation for Building the Conservation Capacity of Community Ecology}

\author{
Sinead M. Crotty ${ }^{1}$, Andrew H. Altieri ${ }^{1}$, John F. Bruno ${ }^{2}$, Hallie Fischman ${ }^{3}$ and \\ Mark D. Bertness ${ }^{3 *}$
}

${ }^{1}$ Department of Environmental Engineering Sciences, University of Florida, Gainesville, FL, United States, ${ }^{2}$ Department of Biology, The University of North Carolina at Chapel Hill, Chapel Hill, NC, United States, ${ }^{3}$ Department of Ecology and Evolutionary Biology, Brown University, Providence, Rl, United States

Ecology is a young discipline that needs to develop into a predictive science to confront the challenges of human population pressures and habitat degradation. Basic ecology has disproportionately focused on undisturbed, charismatic ecosystems, species and academic questions, leaving gaps in its ability to inform the conservation and management of degraded, threatened ecosystems. Foundation species-dependent organisms have been studied at the expense of the habitat-forming species that build and maintain communities. We used cobble beaches as a model system to discuss the consequences of this disparity on translational ecology. We suggest that the historic development of ecology has led to an academic discipline ill-suited for proactive conservation. We propose that the incorporation of foundation species and a hierarchical organization theory, into the conceptual framework of ecology, will improve its predictive ability and successful application in conservation and the restoration of degraded ecosystems.

Keywords: conservation biology, experimental ecology, foundation species, hierarchical organization, natural history

\section{INTRODUCTION}

Understanding the physical and biological forces that create patterns in biotic communities and ecosystems is the major goal of ecology. Community, evolutionary, and conservation ecology have grown from a common ancestry of natural history. In spite of this, ecology has been challenged in its ability to develop into a predictive science informing the management and restoration of threatened or damaged systems (Wallington et al., 2005). Due to the barriers created by the historic development of ecology, conservation practice has been piecemeal, differing across ecological systems, and has been predominantly reactive, rather than proactive (Brooks et al., 2006; Sutherland et al., 2011; Cook et al., 2013, 2014). A unified translational conceptual ecology framework based on the fundamental role of a hierarchical community organization is needed to confront the contemporary conservation crisis. 


\section{A BRIEF HISTORY OF ECOLOGY}

Originating from the seminal science of natural history observation, ecology developed to explain processes and patterns in natural communities (Odum, 1953; Krebs, 1972). Contemporary ecology and evolutionary biology grew from global exploration voyages of the 19th and early 20th Centuries. Darwin and Wallace pioneered the study of evolution on these voyages (Darwin, 1859). Ecology pioneers like Tansley and Clements described species and studied spatial patterns to build the conceptual foundation of ecology (Tansley, 1935; Clements, 1936). Their work was correlative, assumed causation from correlation, and led to the quantification of species distributions relative to abiotic variables-a hallmark of ecology in the first half of the 20th century.

From this descriptive beginning, theoretical ecology focused on niches, competition, and trophic dynamics. Gause's (1934) "Struggle for Existence" painted an ecological framework echoing Darwin's work. Grinnell, Elton, and Hutchinson developed a niche theory based on distribution and abundance patterns, reflecting physical tolerances and competitive interactions among species (Grinnell, 1917; Elton, 1927; Hutchinson, 1957). This era influenced ecological theories, such as Garret Hardin's competitive exclusion principle (Hardin, 1960) and Eugene Odum's ecosystem superorganism concept (Odum, 1969), which assumed ecosystem equilibrium but ignored the dynamic fluxes and disequilibrium that are conspicuous in the field.

Hypothesis-driven field experiments (Connell, 1961; Paine, 1966) led to recognition of disturbance (Dayton, 1971) and its role in structuring natural communities. Experimental ecology further demonstrated the limited ability of correlations to provide mechanistic answers in community ecology. Hutchinson's "Ecological Theater and the Evolutionary Play" (Hutchinson, 1969) metaphor captured our contemporary view of how natural evolutionary and ecological processes generate patterns in nature. But, this recognition of a unified theoretical framework of ecological pattern generation came shortly before recognition that all ecosystems on Earth were impacted by the unnatural human influences of overexploitation of resources, eutrophication, and climate change driven by our unchecked population growth (Vitousek, 1994; Steffen et al., 2007; Halpern et al., 2008; Estes et al., 2011). As these stressors have intensified in spatial extent, severity, and/or frequency, the conservation of natural systems has been affected by shifting baselines syndrome (Pauly, 1995) and "generational amnesia" (Alleway and Connell, 2015), where "healthy" baselines and expectations for ecosystem services are continuously shifted toward lower, more degraded states.

\section{PROBLEMS UNITING CONCEPTUAL ECOLOGY AND CONSERVATION BIOLOGY}

Attempts to apply ecological principles to conservation practice exposed inherent problems that limit the value of ecology as a predictive, applied science (Balmford and Cowling, 2006; Kareiva et al., 2017). One primary issue is that ecology is strongly habitat, taxa, and community biased, and lacks a unified conceptual framework (Lawton, 1999; Meine et al., 2006). Animal and plant ecologists use different terminology, are commonly described by systems in which they work, and produce results that are often habitat-specific and not generalized. Even assembly rules and operational definitions of concepts differ among subfields, begging the question: can ecology become more than a collection of case studies?

The information era has created new problems for developing a predictive, mechanistic, understanding of community ecology. The drift toward summaries and/or meta-analyses of databases and existing information, rather than field observations and experiments in natural systems has slowed progress in the discipline and prevents ecology from becoming a predictive science. Review papers can be useful as hypothesis generating tools and for identifying gaps in understanding but place a potentially detrimental focus on past research (Schmidt and Hunter, 2014). We argue that a hypothesis-driven, experimental path is needed to synthesize ecology, evolution and conservation into the predictive science needed to confront conservation challenges into the future.

Analogous to the recognition by molecular geneticists that not all gene sequences are equally important, experimental ecology has shown that not all species are equally important in structuring communities and provisioning ecosystem functionality. First described by Dayton (1972), foundation species are abundant organisms that provide habitat templates for communities. Across most ecosystems, foundation species significantly alter physical and biological stress regimes, promoting increases in biodiversity, function, and overall ecosystem development (Stachowicz, 2001; Angelini et al., 2015; Ramus et al., 2017). Most ecosystems can therefore be viewed as hierarchically organized, since the community of inhabitants and their network of ecological interactions are dependent on the setting created by foundation species. In contrast to the highly abundant foundation species, keystone species are those that have a disproportionately large impact despite their low abundance (Power et al., 1996) and their importance can become more apparent as human stressors amplify, interact, and alter the trophic structure of ecological communities (Jordán, 2009). There is an ongoing debate in the literature regarding exact definitions of these terms (Mills et al., 1993) and the context of if and when foundation species may have disproportionate, keystone effects (Coleman and Williams, 2002). Nonetheless, the breadth of their potential interactions and the depth of their reach into the community means that both foundation species and keystone species typically require hypothesis-driven field experiments to identify, rendering species lists and diversity metrics good descriptors, but largely useless as predictors without underlying mechanisms.

\section{COBBLE BEACHES AS MODEL SYSTEMS FOR CONCEPTUAL ECOLOGY}

We suggest that the conceptual development of modern ecology is in danger of becoming untethered from the natural history 
field acumen of ecology's founders, and that the lack of this grounding will obscure the development of an inclusive, robust and predictive ecology. We explore this perspective using cobble beach community model systems. Most ecosystems are defined by foundation species and illustrate the importance of a hierarchical organization and the contribution of keystone species. We use cobble beaches because they are rare relative to the important role they have played in developing ecological theory, making them "keystone" in their contribution to the advancements of conceptual ecology.

Cobble beaches occur where glaciers from Pleistocene ice ages crushed and eroded bedrock into boulders, cobble, and sediment. In North America, the mass of the $2.5 \mathrm{~km}$-thick Laurentide Ice Sheet covering an area exceeding 13,000,000 $\mathrm{km}^{2}$ compacted, crushed, fractured, scoured and depressed underlying bedrock. The resulting dislodged rocks, sediment, and debris were pushed by advancing glaciers or deposited as the ice retreated. These processes created capes, coastal islands, and rocky and cobble beaches where shorelines were scoured, and rock debris was deposited (Packham and Willis, 1997).

While cobble beaches have recently attracted the attention of ecologists, they have played a pivotal role at important stages in the development of conceptual ecology. Cobble beaches harbor foundation species-dependent communities at experimentally manageable spatial scales and have disproportionately contributed to a mechanistic understanding of community assembly and dynamics directly applicable to management and conservation. In particular, the dependency of biological communities on substrate stability and positive species interactions was experimentally elucidated in this system (Bruno, 2000; Bruno and Bertness, 2001).

The first general idea that grew from cobble beaches featured the consequences of disequilibrium rather than stability and equilibrium - the intermediate disturbance hypothesis (IDH). Early ecologists avoided disturbed habitats, leading to the assumption that communities existed in equilibrium, a problematic belief for conservation ecology as nearly all are disturbed from their natural state due to human impacts (Watson et al., 2016). This bias became fixed in early ecological theory until Dayton (1971) and Platt's (1975) work in rocky intertidal and grassland ecosystems, respectively, pointed to the role of disturbance in structuring communities. This work inspired cobble beach studies by Sousa (1979) showing that maximum species diversity and richness occur on intermediately sized rocks large enough to prevent constant disturbance and colonization by weedy species, but small enough so they were disturbed occasionally which limited the emergence of a competitive dominant. The development of the IDH (Connell, 1978; Sousa, 1979) freed ecologists from the constraint of equilibrium and was exported and extrapolated extensively to virtually all communities. Future insights were based on the transitional nature of cobble beaches lying between muddy beaches and boulder fields, their interaction with the physical forces that cause stress and instability, and the dependency on positive biotic interactions for structuring the communities that inhabit them (van Wesenbeeck et al., 2007).

\section{FOUNDATION SPECIES AND ECOSYSTEM ENGINEERS}

Foundation species are abundant organisms that provide habitat and infrastructure templates for communities (Dayton, 1972). Ahead of its time, Dayton's foundation species work did not fit into the food web-based conceptual ecology developing at the time and contradicted Paine's (1966) idea that keystone species were the most important drivers of species diversity by suggesting that habit-forming organisms were the primary determinant of biodiversity patterns, rather than the species that ate them. Dayton (1972) coined the term foundation species working with sponges in Antarctica, and then popularized the term through his work with intertidal algal canopy communities that provided shading, water retention, and thermal stability during low tide exposure to physically stressful terrestrial conditions, and acted as a refuge from consumers during high tide foraging (Dayton, 1975). Without the stress amelioration provided by the algal canopy, the understory organisms suffered increased mortality from physical and biological stressors. Foundation species structure ecological communities by providing physical structure and stress amelioration across most ecological systems, whether they are algal canopy, forest canopy, coral reefs, mussel or oyster beds or seagrass meadows (Bruno and Bertness, 2001; Ellison et al., 2005; Angelini et al., 2011; Altieri and van de Koppel, 2013).

Despite early development of the foundation species concept, the general importance of foundation species in biological communities was not recognized until the critical role of positive feedbacks for community persistence and stability became apparent in plant communities (Wilson and Agnew, 1992). Positive feedback switches were proposed to be common in community assembly, occurring when species ameliorated physically stressful habitats, and improved growth and survival conditions for themselves and others. One of the first experimental examples was the foundational role of cordgrass colonization of cobble beaches. Foundational cordgrass was shown to transform areas characterized by low-diversity, high disturbance, mobile, rolling rocks to biodiverse, stabilized habitats that hosted a guild of plants that could develop into fringing salt marshes replete with the plant zonation, interspecific competition, facultative plant-animal mutualisms and ecosystem services that characterize salt marshes (Bruno, 2000). This positive feedback switch is evident in New England salt marshes in sheltered bays where centuries of compact peat accretion often overlay cobble beach foundations (Coverdale et al., 2014). Whole system facilitation of cobble beach plant communities is a long process initiated when cordgrass gains a foothold on barren cobble beaches. Successful cordgrass establishment and lateral expansion leads to development of compacted organic root debris and sediment, and, if not disturbed in early stages, develops a peat foundation. This peat foundation buffers cobble shorelines from wave energy, limits cobble movement by binding cobbles to the beach, and dissipates wave energy, creating low wave energy refugia among cobbles at higher elevations (Figure 1).

As cobble beach cordgrass stands increase in size and robustness through clonal growth, their ability to buffer wave 


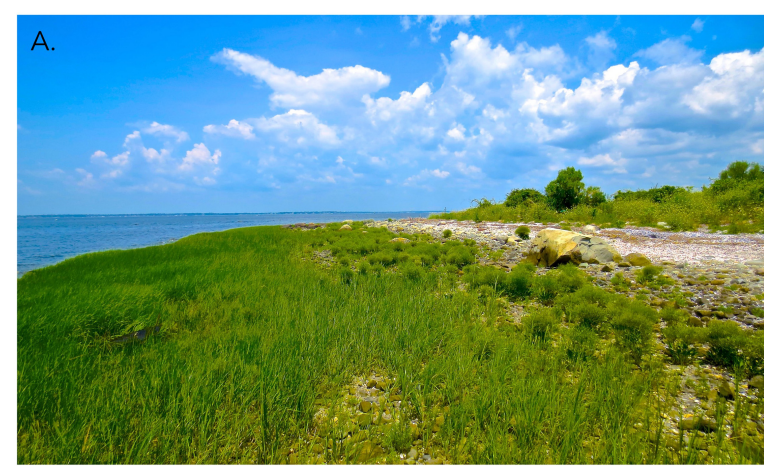

B.

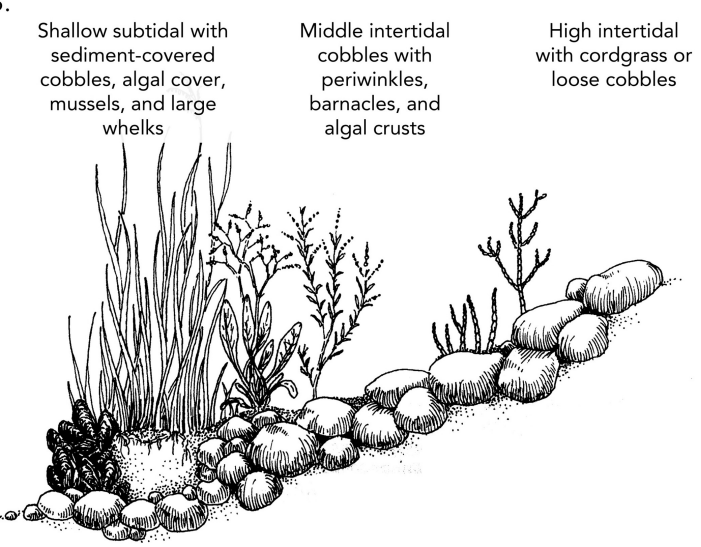

FIGURE 1 | Cobble beach plant communities. Biodiversity and community biomass are dependent on substrate stabilization and buffering of wave stress by cordgrass both within stands of cordgrass and within wave-protected areas behind cordgrass beds of threshold sizes (A). Common cobble beach plants occur behind beds of all sizes, while rare cobble beach plants are only found in the largest beds, shown in (B) (adapted from Bertness, 2007).

energy increases non-linearly, triggering positive feedbacks through increased sedimentation and the recruitment of commensal and facultative mutualists. This further stabilizes the cobble beach plant communities and associated animals. Increasing bed size also leads to the recruitment of rare plant and animal species unable to recruit to or persist in smaller beds with less habitat amelioration. This hierarchical development leads to a strong positive relationship between bed size and plant community species richness, recruitment, and persistence (Bruno, 2002).

In addition to foundation species, the role of allogenic ecosystem engineers, or organisms that transform resources from one state to another (Jones et al., 1994; Coleman and Williams, 2002), in driving community pattern formation was identified in cobble beach communities. Experimental examination of the impact of the invasive European Periwinkle, Littorina littorea (hereafter Littorina), to North American shorelines revealed dramatic habitat change mediated by snail engineering (Bertness, 1984). This herbivorous snail was introduced to Nova Scotia in the mid-19th century, but quickly invaded south to Chesapeake Bay where it filled an apparently empty niche created by the retreat of Pleistocene glaciers, frequent winter icing, and the industrial revolution that had eradicated all but the weedy, fast growing and early reproducing species (Wethey, 1985). As a result, Littorina quickly became the most abundant grazer on New England rocky shores.

On southern New England cobble beaches, Littorina removal experiments revealed their role as keystone grazers because their activity and feeding behavior engineered the structure of the shoreline, mediating whether cobble beaches remained bare or transitioned to cordgrass stands on muddy beaches with abundant associated fauna and flora. Within a month, snail removal cages had a lush canopy of ephemeral green algae and were blanketed with sediment that buried and suffocated sessile organisms. Cages with snails remained entirely free of algae and sediment. Three months after the snail removal, control cages remained sediment and algal free, while infaunal worm and mud crab larvae recruited to the sediment and algal covered ungrazed cobble. The following year cordgrass rhizomes invaded muddy snail removal areas along with their facultative mutualist mussels and fiddler crabs (Supplementary Figure S1). When the experiment ended and snails were allowed to return to all plots, this process reversed as sediment and cordgrass retreated. The experimental evidence was clear; Narragansett Bay cobble beaches were on an ecological tipping point and the presence or absence of invasive snails engineered whether shorelines were sedimentfree with barnacles, or biodiverse muddy, incipient salt marshes (Bertness, 1984).

\section{HIERARCHICAL ORGANIZATION AND FACILITATION CASCADES}

Foundation species have particularly powerful effects when they overlap in facilitation cascades. These indirect positive interactions occur when a primary foundation species alleviates stress to facilitate a secondary foundation species and together, they support a larger, more diverse community with increased ecosystem functionality than either foundation species alone (Altieri et al., 2007; Gedan et al., 2014; Thomsen et al., 2018). Facilitation cascades are another emergent trait of cobble beach communities. On southern New England cobble beaches, the secondary foundation species and mutualist ribbed mussel, Geukensia demissa, settles gregariously on cordgrass roots. Once established, mussel shells provide hard substrate for the recruitment of barnacles and seaweed and crevice space for mobile organisms. This hierarchical organization of foundation species leads to a facilitation cascade of marine organisms and cobble beach vascular plant communities (Altieri et al., 2007). Additional studies revealed that secondary foundation species consistently increase the abundance and richness of associated communities across spatial scales, latitudes, and ecosystems including wetlands, coral, mussel and oyster reefs, terrestrial forests and sand dunes-a finding that has implications for robust community assembly rules and the conceptual core and basic assumptions of community ecology theory (Supplementary Table S1) (Bell and Westoby, 1987; Hall and Bell, 1988; Pettersson et al., 
1995; Castro et al., 2004; Ellwood and Foster, 2004; MacDonald et al., 2008; Thomsen, 2010; Angelini and Silliman, 2014; Thomsen et al., 2016).

\section{INCORPORATING FACILITATION THEORY INTO CONSERVATION BIOLOGY}

Textbook ecology and its extrapolation to conservation continue to be based on niche theory and the competitive exclusion principle. But the use of niche theory to predict species distributions has been questioned by findings on cobble beach ecosystems. The prevailing theory predicts that the spatial and temporal space that a species can survive in allopatry, the fundamental niche, is larger than the realized niche that a species occupies with biotic interactions or in sympatry, particularly owing to competition (Chase and Leibold, 2003). Experimental studies on cobble beaches, however, have shown that by ameliorating physical and biological stresses, foundation species not only impose hierarchical organization on communities, but dramatically increase the size of realized niche space at biological and physical stress extremes. Inclusion of positive interactions, by altering the predictions of niche theory, can more accurately predict distribution patterns in nature (Figure 2A; Crotty and Bertness, 2015). Evidence for this revised niche theory is apparent in a variety of ecosystems, including corals that generate physical structure and productivity on oligotrophic reef habitats
(Knowlton and Jackson, 2001), trees that provide structure, trophic resources, and habitat amelioration to understory food webs (Ellison et al., 2005), and beavers that engineer temperate forests into habitat for wetland plants (Naiman et al., 1988). Seagrass meadows, mangroves, and mussel and oyster reefs provide additional examples of foundation species extending the range of associated organisms beyond their predicted area through amelioration of physically and/or biologically stressful environments.

Human impacts on foundation species and ecosystem engineers have illustrated the inadequacy of competition-based niche theory. The great dust bowl of the American plains, desertification of over-harvested forests, and the ongoing dieoff of oyster and coral reefs, salt marshes, seagrasses, and mangroves forests all have unique proximate causes. However, the common denominator among all of these examples is the loss of foundation species leading to system collapse (Intergovernmental Panel on Climate Change [IPCC], 2014). The general lessons from these events-that facilitation is as ubiquitous an interaction as competition and that the hierarchical overlap of foundation species is often responsible for ecosystem structure, function, resilience, and recovery potential-needs to be incorporated into mainstream conservation biology and associated proactive management prescriptions (Gedan and Silliman, 2009; Thurstan et al., 2013; Fariñas-Franco et al., 2018). Where ecological systems are already perturbed, restoration ecology can and should become the experimental testing ground for predictive community ecology based on

\section{A Niche Theory}
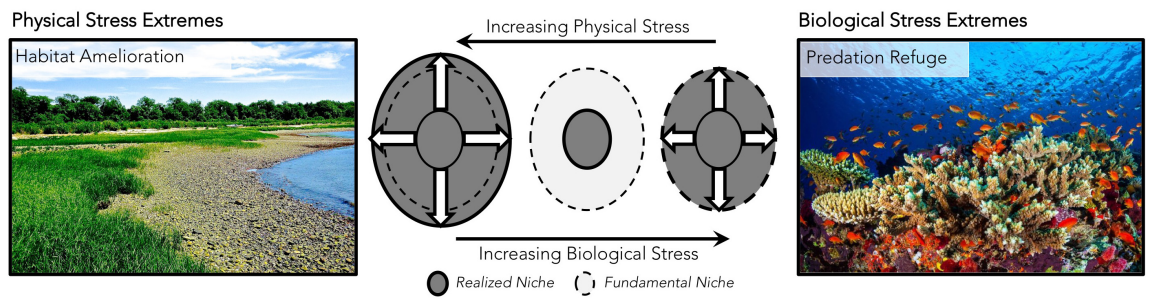

B Models of Community Organization
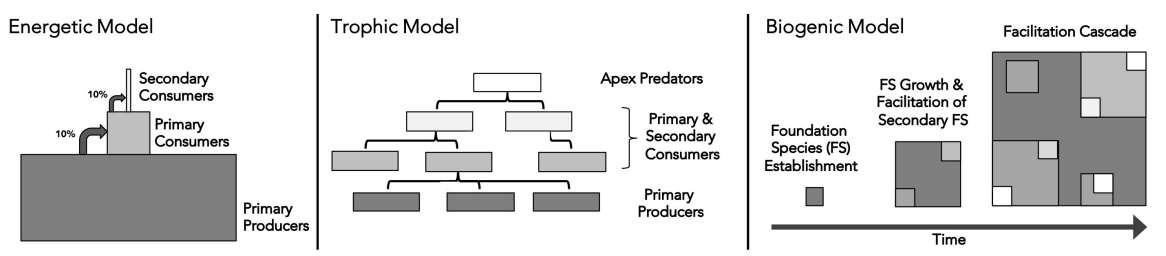

FIGURE 2 | Conceptual models incorporating positive interactions into (A) niche theory (adapted from Crotty and Bertness, 2015) and (B) models of community organization. (A) Contradicting traditional niche theory, this model predicts that the realized niche will be larger than the fundamental niche in physically stressful habitats through habitat amelioration and will be identical to the fundamental niche in biologically stressful habitats through associational defenses. The areas enclosed by dashed lines represent the fundamental niche space. Gray areas outlined by solid black lines represent realized niche space along physical and biological stress gradients. Physical stress extremes (left) are shown as cobble beach habitats, where most littoral organisms are unable to persist without the presence of the foundational cordgrass. Biological stress extremes are shown (right) within marine environments, where corals provide refuge to smaller prey species, allowing them to persist in areas otherwise exposed to high rates of predation-related mortality. (B) Traditional energetic models, food web trophic models, and biogenic model of community organization are presented to highlight conceptual differences about community organization. Lighter shapes signify higher trophic levels, while dark colors signify basal tropic levels in all panels. The biogenic model considers the cascading effects of multiple, overlapping foundation species and niche segregation within a foundation species template through time. 
this new understanding. In the few instances where facilitation theory has begun to inform restoration design, the results have been overwhelmingly positive-providing support for the idea that utilizing the hierarchical organization perspective of foundation species, and the associated positive feedbacks, will be critically important for enhancing the recovery and resilience of ecological systems as anthropogenic stressors intensify and degrade ecosystems (Silliman et al., 2015; Derksen-Hooijberg et al., 2017; Supplementary Box S1).

\section{BUILDING A PREDICTIVE PRACTICAL COMMUNITY ECOLOGY}

To date, community ecology has largely been an academic exercise that has not reached its potential as a predictive applied science. It has produced an intellectually satisfying body of literature and theory that explains the pattern and dynamics of biotic communities but has generally been reactive when challenged with large local and global anthropogenic threats. It is commonly believed that the failures of ecology as a translational science are a communication problem (Sutherland et al., 2006; Jacobson et al., 2015). We disagree. While communication is important, it needs a clear intuitive message to succeed. We suggest that these failures are instead a conceptual problem based on the inability to apply traditional niche, energetic, and trophic models to solve problems in the conservation, management, and restoration of threatened ecosystems. These models are valuable metrics for evaluating ecosystem health and understanding the functional and dysfunctional dynamics

\section{REFERENCES}

Alleway, H. K., and Connell, S. D. (2015). Loss of an ecological baseline through the eradication of oyster reefs from coastal ecosystems and human memory. Conserv. Biol. 29, 795-804. doi: 10.1111/cobi.12452

Altieri, A. H., Silliman, B. R., and Bertness, M. D. (2007). Hierarchical organization via a facilitation cascade in intertidal cordgrass bed communities. Am. Nat. 169, 195-206. doi: 10.1086/510603

Altieri, A. H., and van de Koppel, J. (2013). "Foundation species in marine ecosystems," in Marine Community Ecology and Conservation, eds M. D. Bertness, J. F. Bruno, B. R. Silliman, and J. J. Stachowicz (Sunderland, MA: Sinauer Associates), 37-56.

Angelini, C., Altieri, A. H., Silliman, B. R., and Bertness, M. D. (2011). Interactions among foundation species and their consequences for community organization, biodiversity, and conservation. Bioscience 61, 782-789. doi: 10.1525/bio.2011. 61.10 .8

Angelini, C., van der Heide, T., Griffin, J. N., Morton, J. P., Derksen-Hooijberg, M., Lamers, L. P., et al. (2015). Foundation species' overlap enhances biodiversity and multifunctionality from the patch to landscape scale in southeastern United States salt marshes. Proc. R. Soc. B 282:20150421. doi: 10.1098/rspb. 2015.0421

Angelini, C. A., and Silliman, B. R. (2014). Secondary foundation species as drivers of trophic and functional diversity: evidence from a tree-epiphyte system. Ecology 95, 185-196. doi: 10.1890/13-0496.1

Balmford, A., and Cowling, R. M. (2006). Fusion or failure? The future of conservation biology. Conserv. Biol. 20, 692-695. doi: 10.1111/j.1523-1739. 2006.00434.x

Bell, J. D., and Westoby, M. (1987). Effects of an epiphytic alga on abundances of fish and decapods associated with the seagrass Zostera capricorni. Aust. J. Ecol. 12, 333-337. doi: 10.1111/j.1442-9993.1987.tb00954.x of biological communities, but do not address the system ontogeny that is key to the resilience and recovery of damaged ecosystems (Figure 2B). The solution is a simpler biogenic model of a community structure based on the fundamental importance of foundation species and ecosystem engineers, the hierarchical organization generated by these critical species, and the role of facilitation cascades in driving the structure, function, and positive feedbacks that underpin the resilience of biotic communities. Adopting this perspective will allow ecology to develop into a predictive applied science needed for the future success of conservation, management and restoration.

\section{AUTHOR CONTRIBUTIONS}

MB and SC wrote the first draft of the manuscript. All authors revised the manuscript.

\section{FUNDING}

This work was supported by the NSF GRFP DGE1315138 award to SC.

\section{SUPPLEMENTARY MATERIAL}

The Supplementary Material for this article can be found online at: https://www.frontiersin.org/articles/10.3389/fmars. 2019.00238/full\#supplementary-material

Bertness, M. D. (1984). Habitat and community modification by an introduced herbivorous snail. Ecology 65, 370-381. doi: 10.2307/194 1400

Bertness, M. D. (2007). Atlantic Shorelines: Natural History and Ecology. Princeton, NJ: Princeton University Press, 446.

Brooks, T. M., Mittermeier, R. A., da Fonseca, G. A. B., Gerlach, J., Hoffmann, M., Lamoreux, J. F., et al. (2006). Global biodiversity conservation priorities. Science $313,58-61$.

Bruno, J. F. (2000). Facilitation of cobble beach plant communities through habitat modification by Spartina alterniflora. Ecology 81, 1179-1192. doi: 10.1890/ 0012-9658(2000)081\%5B1179:focbpc\%5D2.0.co;2

Bruno, J. F. (2002). Causes of nested species distributions and landscape-scale rarity in cobble beach plant communities. Ecology 83, 2304-2314. doi: 10.1890/00129658(2002)083\%5B2304:colsri\%5D2.0.co;2

Bruno, J. F., and Bertness, M. D. (2001). "Habitat modification and facilitation in benthic marine communities," in Marine Community Ecology, eds M. D. Bertness, S. D. Gaines, and M. E. Hay (Sunderland, MA: Sinauer Associates), 201-220.

Castro, J., Zamora, R., Hodar, J. A., Gómez, J. M., and Gómez-Aparicio, L. (2004). Benefits of using shrubs as nurse plants for reforestation in mediterranean mountains: a 4-year study. Restor Ecol. 12, 352-358. doi: 10.1111/j.1061-2971. 2004.0316.x

Chase, J. M., and Leibold, M. A. (2003). Ecological Niches: Linking Classical and Contemporary Approaches. Chicago, IL: University of Chicago Press, 212.

Clements, F. E. (1936). Nature and structure of the climax. J. Ecol. 24, 252-284.

Coleman, F. C., and Williams, S. L. (2002). Overexploiting marine ecosystem engineers: potential consequences for biodiversity. Trends Ecol. Evol. 17, 40-44. doi: 10.1016/s0169-5347(01)02330-8 
Connell, J. H. (1961). The influence of interspecific competition and other factors on the distribution of the barnacle Chthamalus stellatus. Ecology 42, 710-723. doi: $10.2307 / 1933500$

Connell, J. H. (1978). Diversity in tropical rain forests and coral reefs. Science 199, 1302-1310. doi: 10.1126/science.199.4335.1302

Cook, C., Wintle, B. C., Aldrich, S., and Wintle, B. A. (2014). Using strategic foresight to assess conservation opportunity. Cons. Biol. 28, 1474-1483. doi: 10.1111/cobi. 12404

Cook, R., Fariñas-Franco, J. M., Gell, F. R., Holt, R. H., Holt, T., Lindenbaum, C., et al. (2013). The substantial first impact of bottom fishing on rare biodiversity hotspots: a dilemma for evidence-based conservation. PLoS One 8:e69904. doi: 10.1371/journal.pone.0069904

Coverdale, T. C., Young, E. W., Brisson, C. P., Yin, S. F., Donnelly, J. P., Bertness, M. D., et al. (2014). Decades of die-off reverse centuries of carbon sequestration and salt marsh accretion. PLoS One 9:e93296. doi: 10.1371/ journal.pone.0093296

Crotty, S. M., and Bertness, M. D. (2015). Positive interactions expand habitat use and the realized niches of sympatric species. Ecology 96, 2575-2582. doi: 10.1890/15-0240.1

Darwin, C. (1859). On the Origin of Species by Means of Natural Selection. London: John Murray.

Dayton, P. K. (1971). Competition, disturbance, and community organization: the provision and subsequent. utilization of space in a rocky intertidal community. Ecol. Monogr. 41, 351-389. doi: 10.2307/1948498

Dayton, P. K. (1972). "Toward an understanding of community resilience and the potential effects of enrichments to the benthos at McMurdo Sound, Antarctica," in Proceedings of the Colloquium on Conservation Problems in Antarctica, ed. B. C. Parker (Lawrence, KS: Allen Press), 81-95.

Dayton, P. K. (1975). Experimental evaluation of ecological dominance in a rocky intertidal algal community. Ecol. Monogr. 45, 137-159. doi: 10.2307/ 1942404

Derksen-Hooijberg, M., Angelini, C., Lamers, L. P. M., Borst, A., Smolders, A., Hoogveld, J. R. H., et al. (2017). Mutualistic interactions amplify saltmarsh restoration success. J. Appl. Ecol. 55, 405-414. doi: 10.1111/1365-2664.12960

Ellison, A. M., Bank, M. S., Clinton, B. D., Clinton, B. D., Colburn, E. A., Elliott, K., et al. (2005). Loss of foundation species: consequences for the structure and dynamics of forested ecosystems. Front. Ecol. Environ. 9, 479-486. doi: 10.1890/1540-9295(2005)003 \%5B0479:lofscf $\ \% 5$ D2.0.co;2

Ellwood, M. D. F., and Foster, W. A. (2004). Doubling the estimate of invertebrate biomass in a rainforest canopy. Nature 429, 549-551. doi: 10.1038/nature02560

Elton, C. (1927). Animal Ecology (Reprinted 2001 by The University of Chicago Press). London: Sidgwick and Jackson.

Estes, J. A., Terborgh, J., Brashares, J. S., Power, M. E., Berger, J., Bond, W. J., et al. (2011). Trophic downgrading of planet earth. Science 333, 301-306. doi: 10.1126/science.1205106

Fariñas-Franco, J. M., Allcock, L. A., and Roberts, D. (2018). Protection alone my not promote natural recovery of biogenic habitats of biodiversity damaged by mobile fishing gears. Mar. Environ. Res. 135, 18-28. doi: 10.1016/j.marenvres. 2018.01.009

Gause, G. F. (1934). The Struggle for Existence. Baltimore, MD: Williams \& Wilkins, 163.

Gedan, K. B., Kellogg, L., and Brietburg, D. L. (2014). Accounting for multiple foundation species in oyster reef restoration benefits. Restor. Ecol. 22, 517-524. doi: $10.1111 /$ rec. 12107

Gedan, K. B., and Silliman, B. R. (2009). Using facilitation theory to enhance mangrove restoration. Ambio 38, 109-109. doi: 10.1579/0044-7447-38.2.109

Grinnell, J. (1917). The niche-relationships of the California Thrasher. Auk 34, 427-433. doi: 10.2307/4072271

Hall, M. O., and Bell, S. S. (1988). Response of small motile epifauna to complexity of epiphytic algae on seagrass blades. J. Mar. Res. 46, 613-630. doi: 10.1357/ 002224088785113531

Halpern, B. S., Walbridge, S., Selkoe, K. A., Kappel, C. V., Micheli, F., D’Agrosa, C., et al. (2008). A global map of human impact on marine ecosystems. Science 319, 948-952.

Hardin, G. (1960). The competitive exclusion principle. Science 131, 1292-1297. doi: $10.1126 /$ science.131.3409.1292

Hutchinson, G. E. (1957). Concluding remarks. Cold Spring Harb. Symp. Quant. Biol. 22, 415-427.
Hutchinson, G. E. (1969). The Ecological Theater and the Evolutionary Play. New Haven, CT: Yale University Press, 139.

Intergovernmental Panel on Climate Change [IPCC] (2014). Climate Change 2014: Synthesis Report. Contribution of Working Groups I, II and III to the Fifth Assessment Report of the Intergovernmental Panel on Climate Change. Geneva: IPCC, 151.

Jacobson, S. K., McDuff, M. D., and Monroe, M. C. (2015). Conservation Education and Outreach Techniques. Oxford: Oxford University Press.

Jones, C. G., Lawton, J. H., and Shachak, M. (1994). Organisms as ecosystem engineers. Oikos 69, 373-386.

Jordán, F. (2009). Keystone species and food webs. Philos. Trans. R. Soc. B Biol. Sci. 364, 1733-1741. doi: 10.1098/rstb.2008.0335

Kareiva, P., Marvier, M., and Silliman, B. (eds) (2017). Effective Conservation Science: Data Not Dogma. Oxford: Oxford University Press.

Knowlton, N., and Jackson, J. B. C. (2001). "The ecology of coral reefs," in Marine Community Ecology, eds M. D. Bertness, S. D. Gaines, and M. E. Hay (Sunderland, MA: Sinauer Associates), 395-422.

Krebs, C. J. (1972). Ecology: The Experimental Analysis of Distribution and Abundance. Manhattan, NY: Harper and Row, 694.

Lawton, J. H. (1999). Are there general laws in ecology? Oikos 84, 177-192.

MacDonald, J. A., Glover, T., and Weis, J. S. (2008). The impact of mangrove prop root epibionts on juvenile reef fishes: a field experiment using artificial roots and epifauna. Estuar Coast. 31, 981-993. doi: 10.1007/s12237-0089083-2

Meine, C., Soule, M., and Noss, R. F. (2006). A mission-driven discipline: the growth of conservation biology. Conserv. Biol. 20, 631-651. doi: 10.1111/j. 1523-1739.2006.00449.x

Mills, L. S., Soulé, M. E., and Doak, D. F. (1993). The keystone-species concept in ecology and conservation. BioScience 43, 219-224. doi: 10.2307/1312122

Naiman, R. J., Johnston, C. A., and Kelley, J. C. (1988). Alteration of north american streams by beaver. BioScience 38, 753-762. doi: 10.2307/1310784

Odum, E. P. (1953). Fundamentals of Ecology. Philadelphia, PA: Saunders, 384.

Odum, E. P. (1969). The strategy of ecosystem development. Science 164, 262-270. doi: $10.1126 /$ science.164.3877.262

Packham, J. R., and Willis, A. J. (1997). Ecology of Dunes, Salt Marsh and Shingle. Berlin: Springer Science \& Business Media.

Paine, R. T. (1966). Food web complexity and species diversity. Am. Nat. 100, 65-75. doi: $10.1086 / 282400$

Pauly, D. (1995). Anecdotes and the shifting baseline syndrome of fisheries. Trends Ecol. Evol. 10:430. doi: 10.1016/s0169-5347(00)89171-5

Pettersson, R. B., Ball, J. P., Renhorn, K. E., and Essen, P. A. (1995). Invertebrate communities in boreal forest canopies as influenced by forestry and lichens with implications for passerine birds. Biol. Conserv. 74, 57-63. doi: 10.1016/00063207(95)00015-v

Platt, W. J. (1975). The colonization and formation of equilibrium associations on badger disturbances in tall-grass prairie. Ecol. Monogr. 45, 285-305. doi: $10.2307 / 1942425$

Power, M. E., Tilman, D., Estes, J. A., and Menge, B. A. (1996). Challenges in the quest for keystones: identifying keystone species is difficult-but essential to understanding how loss of species will affect ecosystems. BioScience 46, 609-620.

Ramus, A. P., Silliman, B. R., Thomsen, M. S., and Long, Z. T. (2017). An invasive foundation species enhances multifunctionality in a coastal ecosystem. Proc. Natl. Acad. Sci. U.S.A. 114, 8580-8585. doi: 10.1073/pnas.170035 3114

Schmidt, F. L., and Hunter, J. E. (2014). Methods of Meta-Analysis: Correcting Error and Bias in Research Findings. Thousand Oaks, CA: SAGE Publications.

Silliman, B. R., Schrack, E., He, Q., Cope, R., Santoni, A., van der Heide, T., et al. (2015). Facilitation shifts paradigms and can amplify coastal restoration efforts. Proc. Natl. Acad. Sci. U.S.A. 112, 14295-14300. doi: 10.1073/pnas.151529 7112

Sousa, W. P. (1979). Disturbance in marine intertidal boulder fields: the nonequilibrium maintenance of species diversity. Ecology 60, 1225-1239.

Stachowicz, J. (2001). Mutualism, facilitation, and the structure of ecological communities. BioScience 51, 235-246. doi: 10.1126/science.aai8212

Steffen, W., Crutzen, P. J., and McNeill, J. R. (2007). The anthropocene: are humans now overwhelming the great forces of nature? Ambio 36, 614-621. doi: 10.1579/0044-7447(2007)36\%5B614:taahno\%5D2.0.co;2 
Sutherland, W. J., Armstrong-Brown, S., Armsworth, P. R., Brereton, T., and Brickland, J. (2006). The identification of 100 ecological questions of high policy relevance in the UK. J. Appl. Ecol. 43, 617-627. doi: 10.1111/j.1365-2664.2006. 01188.x

Sutherland, W. J., Fleishman, E., Mascia, M. B., Pretty, J., and Rudd, M. A. (2011). Methods for collaboratively identifying research priorities and emerging issues in science and policy. Methods Ecol. Evol. 2, 238-247. doi: 10.1111/j.2041-210x. 2010.00083.x

Tansley, A. G. (1935). The use and abuse of vegetational concepts and terms. Ecology 16, 284-307. doi: 10.2307/1930070

Thomsen, M. S. (2010). Experimental evidence for positive effects of invasive seaweed on native invertebrates via habitat-formation in a seagrass bed. Aquat. Invasions 5, 341-346. doi: 10.3391/ai.2010.5.4.02

Thomsen, M. S., Altieri, A. H., Angelini, C., Bishop, M. J., Gribben, P. E., Lear, G., et al. (2018). Secondary foundation species enhance biodiversity. Nat. Ecol. Evol. 2, 634-639. doi: 10.1038/s41559-018-0487-5

Thomsen, M. S., Metcalfe, I., South, P., and Schiel, D. R. (2016). A host-specific habitat former controls biodiversity across ecological transitions in a rocky intertidal facilitation cascade. Mar. Freshw. Res. 67, 144-152.

Thurstan, R., Hawkins, J. P., Raby, L., and Roberts, C. M. (2013). Oyster (Ostrea edulis) extirpation and ecosystem transformation in the Firth of Forth. Scotland. J. Nat. Conserv. 21, 253-261. doi: 10.1016/j.jnc.2013. 01.004

van Wesenbeeck, B. K., Crain, C. M., Altieri, A. H., and Bertness, M. D. (2007). Distinct habitat types arise along a continuous hydrodynamic stress gradient due to interplay of competition and facilitation. Mar. Ecol. Prog. Ser. 349, 63-71. doi: $10.3354 /$ meps 07051
Vitousek, P. M. (1994). Beyond global warming: ecology and global change. Ecology 75, 1861-1876. doi: 10.2307/1941591

Wallington, T. J., Hobbs, R. J., and Moore, S. A. (2005). Implications of current ecological thinking for biodiversity conservation: a review of the salient issues. Ecol. Soc. 10:15. doi: 10.1007/978-1-4020-5734-2_3

Watson, J. E. M., Shanahan, D. F., Di Marco, M., Allan, J., Laurance, W. F., Sanderson, E. W., et al. (2016). Catastrophic declines in wilderness areas undermine global environmental targets. Curr. Biol. 26, 2929-2934. doi: 10. 1016/j.cub.2016.08.049

Wethey, D. S. (1985). Catastrophe, extinction, and species diversity: a rocky intertidal example. Ecology 66, 445-456. doi: 10.2307/ 1940393

Wilson, J. B., and Agnew, A. D. Q. (1992). Positive-feedback switches in plant communities. Adv. Ecol. Res. 23, 263-336. doi: 10.1016/s0065-2504(08) 60149-x

Conflict of Interest Statement: The authors declare that the research was conducted in the absence of any commercial or financial relationships that could be construed as a potential conflict of interest.

Copyright (c) 2019 Crotty, Altieri, Bruno, Fischman and Bertness. This is an openaccess article distributed under the terms of the Creative Commons Attribution License (CC BY). The use, distribution or reproduction in other forums is permitted, provided the original author(s) and the copyright owner(s) are credited and that the original publication in this journal is cited, in accordance with accepted academic practice. No use, distribution or reproduction is permitted which does not comply with these terms. 